\title{
Photo-induced deformations in azobenzene-containing side-chain polymers: molecular dynamics study
}

\author{
J.Inytskyi*1,3, M.Saphiannikova², D.Neher ${ }^{1}$ \\ ${ }^{1}$ Institute for Physics, University of Potsdam, \\ Am Neuen Palais 10, 14469 Potsdam, Germany \\ 2 Leibniz Institute of Polymer Research, \\ Hohe Str. 6, 01069 Dresden, Germany \\ 3 Institute for Condensed Matter Physics, \\ National Academy of Sciences of Ukraine, \\ 1 Svientsitskii Str., 79011 Lviv, Ukraine
}

Received August 28, 2005, in final form January 23, 2006

\begin{abstract}
We perform molecular dynamics simulations of azobenzene containing side-chain liquid crystalline polymer subject to an external model field that mimicks the reorientations of the azobenzenes upon irradiation with polarized light. The smectic phase of the polymer is studied with the field applied parallel to the nematic director, forcing the trans isomers to reorient perpendicularly to the field (the direction of which can be assosiated with the light polarization). The coupling between the reorientation of azobenzenes and mechanical deformation of the sample is found to depend on the field strength. In a weak field the original smectic order is melted gradually with no apparent change in the simulation box shape, whereas in a strong field two regimes are observed. During the first one a rapid melting of the liquid crystalline order is accompanied by the contraction of the polymer along the field direction (the effect similar to the one observed experimentally in azobenzene containing elastomers). During the slower second regime, the smectic layers are rebuilt to accomodate the preferential direction of chromophores perperdicular to the field.
\end{abstract}

Key words: liquid crystals, azobenzene, polymers, molecular dynamics

PACS: $31.15 . \mathrm{Qg}, 64.70 . \mathrm{Md}, 64.70 . \mathrm{Nd}$

\section{Introduction}

Azobenzene-containing polymer materials (here and further on we will use the term "azopolymers") possess unique attractive features due to the trans-cis photoisomerization of the chromophores. On absorbing a photon the planar trans isomer transforms into the bent and twisted cis form, the latter undergoing reverse transformation either by the same mechanism or by thermally induced back isomerization [1], see figure 1. The absorption bands for both photoisomerization processes depend on the chemical nature of the substituents $R, R^{\prime}$. If both bands overlap then the cyclic trans-cis-trans photoisomerization can take place during illumination with single wavelength.

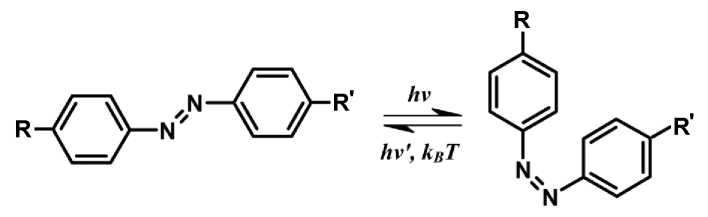

Figure 1. The photoisomerization cycle for azobenzene.

\footnotetext{
*E-mail: iln@icmp.lviv.ua
} 
Unsubstituted trans-azobenzene is a crystalline powder at room conditions with the melting point at $T_{\mathrm{M}}=68-69^{\circ} \mathrm{C}$ (some computer simulations relevant to its crystallisation can be found in $[2])$. Its derivatives have been mostly studied either in solution (acting as dyes) or being dispersed or attached to a polymer framework of various architecture (main-chain, side-chain, elastomeric, dendritic). In the latter case the azobenzene groups act as typical mesogens and induce liquid crystalline (LC) phases [3]. It has further been used as a photo-switchable component in block copolymer system or as a dye dopant combined with other mesogens, e.g. $5 C B$, see $[4,5]$.

Let us concentrate on two particular polymeric architectures, namely LC elastomers and LC side-chain polymers. LC elastomers are rubbers with covalently attached mesogenic units. As the result, there is a strong coupling between nematic order and mechanical stress of the underlying polymeric framework [6]. This leads, for instance, to the remarkable property of nematic elastomers to change their shape reversibly by up to $400 \%$ in the vicinity of their nematic-isotropic (NI) transition [7]. The theory of nematic networks is now well established [8,9]. In chromophore containing LC elastomers the orientational order can be also affected by the light. A large mechanical deformation has been observed experimentally on azobenzene containing LC elastomers with both covalently attached and dissolved azo dyes in response to the non-uniform illumination [10-12].

Unlike LC elastomers, the chains of LC side-chain polymers are not cross-linked and, therefore, are more free to move. One of the new applications of side-chain azo-polymers is the fabrication of sinusoidally modulated surface structures, known as surface relief gratings (SRG). These are produced on thin polymer films using optical setups with various interference patterns similar to the ones used for holographic recordings [13]. The process is all-optical and the SRG films can be applied as diffractive elements and in optical storage media (see, reviews [14,15] and references therein). The main peculiarity of this process is the nature of the force behind this photo-induced large scale mass-transport that takes place in the amorphous state of a polymer. A number of theories have been developed, namely, thermal gradients, diffusive mechanisms, pressure gradients resulting from the isomerization, the superposition of the interactions between the azo dipoles and the electric field of the light interference pattern, and a recent entropic theory (for more detail, see review [15] and [16]). However, none of these is able to describe equally well all the combinations of optical setups and different polymers being used. In fact, a clear microscopical picture of both photo-induced reversible and irreversible changes in azo-polymers is still missing.

The aim of this study is not to perform an in-scale modelling of the photo-induced effects in azopolymers but rather to take a look at some possible microscopic mechanisms behind these. The idea is to simulate the azo-polymer in "dark" and "light" areas and to analyse the mechanical response of the system to the light. To this end we use molecular dynamics simulation with NPT ensemble and anisotropic pressure control. This allows the simulation box to fluctuate independently in all three dimensions while keeping the total pressure equal to the atmospheric one. The change in the shape of the box reflects (with some limitations given below) that of the macroscopic sample and can be seen as an indication of the mechanical response of the system to an external perturbation. The simulations are performed on a side-chain architecture but we expect many similarities to the elastomer system, particularly on a short time scale. The details of the model are presented in the next section.

\section{Model}

Atomic-level modelling of the photo-induced deformations in azo-polymers faces a number of difficulties. For instance, a length scale of the material deformation in SRG is of the order of microns (typical film thickness is about $1 \mu \mathrm{m}$, the grating periodicity is $1-5 \mu \mathrm{m}$ ) and the recording time ranges from seconds to tens of minutes. This length and time scale is clearly beyond the current capabilities of atomistic molecular dynamics simulations, therefore one needs to find ways to speed up the effect being considered. Another issue is the level of required chemical detailization which also influences the speed of the simulations to a great extent. The SRGs are known to be successfully recorded on a great variety of azobenzene containing chemical structures, which can be seen as an indication that the molecular model is not needed to be chemically exact. 
Most types of azo-polymers used for SRG inscription can be split into two groups: the amorphous and LC systems. The terminology evidently originates from the phase in which a particular polymer can be found at moderate temperatures, $T<100^{\circ} \mathrm{C}$. Typical amorphous systems have a short spacer (typically, of 1-4 $\mathrm{CH}_{2}$ groups) which links the azobenzene to the polymer backbone, and, sometimes, a stiffer backbone. The glass transition temperatures $T_{\mathrm{g}}$ are normally above $100^{\circ} \mathrm{C}$. The LC systems, on the contrary, have a relatively long spacer (often of 10 or $\mathrm{more}^{\mathrm{CH}_{2}}$ groups) and, as a result, lower $T_{\mathrm{g}}$. At the temperature interval $T=20^{\circ}-100^{\circ} \mathrm{C}$ these are usually found in the smectic phase.

The photo-induced effects are known to occur on much shorter time-scales in LC azo-polymers. In particular, recordings of SRG within $0.5 \mathrm{~s}$ have been reported [5], as compared to tens of minutes for amorphous systems. For this reason we have chosen this particular architecture for our simulations. The smectic phases inherent to LC azo-polymers may also shed some light on the importance of the aggregation of azobenzenes [17-19], since the rearrangement of these aggregates is expected to be on much shorter time scale in LC azo-polymers. We empolyed the semi-atomistic modelling, in which the $\mathrm{CH}_{\mathrm{n}}$ groups of the alkyl chains are represented as united-atom LennardJones monomers and the azobenzene groups (including possible substituents) are considered to be anisometric units interacting via the Gay-Berne potential [20] with the following parametrisation, $\mu=1, \nu=2, \kappa=3, \kappa^{\prime}=5$. The bonded interactions include bond stretch, bond bending and torsional terms (for more details, see [21]) with the force field developed for branched alkanes [22]. Each polymer consists of a backbone of 39 monomer with 10 side-chains attached to it. Each side-chain has a flexible spacer of 10 monomers terminated by the azo model unit (see, figure 2).

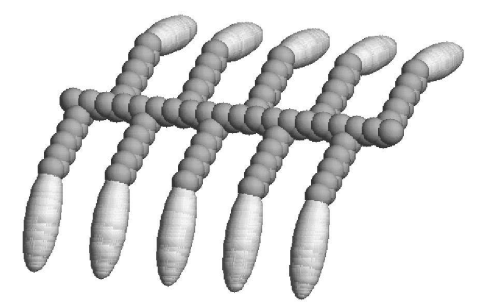

Figure 2. A single side-chain of azo-polymer.

The detailed study of the photoisomerization of azobenzene is beyond the scope of this paper, therefore we employed a simplified statistical description of this effect. It is assumed that the material contains azobenzene with substituents so that rapid cyclic trans-cis isomerization occurs and the photostationary state is quickly established. The trans-cis photoisomerization rate is known to be proportional to $\cos ^{2}(\theta)(\theta$ is the angle between the long axis of the isomer and the light polarization) therefore trans isomers are to be found predominantly perpendicular to the light polarization (where the probability for the photoisomerization is the lowest). This effect can be modelled via an external model field, the energy of each $i$-th trans isomer in a field is

$$
U_{\mathrm{i}}^{\text {field }}=F \cdot P_{2}\left(\cos \left(\theta_{\mathrm{i}}\right)\right) .
$$

Here the field strength is $F>0, \theta_{\mathrm{i}}$ is the angle between the long axis of the $i$-th trans azobenzene and the prescribed direction (here and thereafter referred as the field direction), and $P_{2}(x)=$ $1 / 2\left(3 x^{2}-1\right)$ is the second Legendre polynomial. Unlike the electric or magnetic fields which align the mesogens parallel to a given direction, the field defined via equation 1 forces trans azobenzenes to be confined in the planes perpendicular to the field direction. The angular derivative of $U_{i}^{\text {field }}$ with respect to $\theta_{\mathrm{i}}$ is related to the torque applied to each azobenzene. The cis isomers are not included in our model explicitly.

One should mention that our model lacks some important aspects of photoisomerization, particularly, the existence of cis isomers and the dynamical nature of the photostationary state. The only effect taken into account is the reorientation of the trans isomers of the azobenzenes. 


\section{Results}

At first, our model side-chain LC polymer has been examined with respect to the formation of LC phases. The initial configuration was built by packing 64 side chains (see, figure 2) into the simulation box in some regular layered way (see, figure 3, on the left, here and thereafter we show the snapshots of the polymer contained in one periodic box only). To avoid artificial splitting-up of the polymer at the box edges along $X$ axis, the backbones were positioned to interdigitate throughout the box boundaries and the periodic boundary conditions have been employed (see, figure 3 , in the middle).
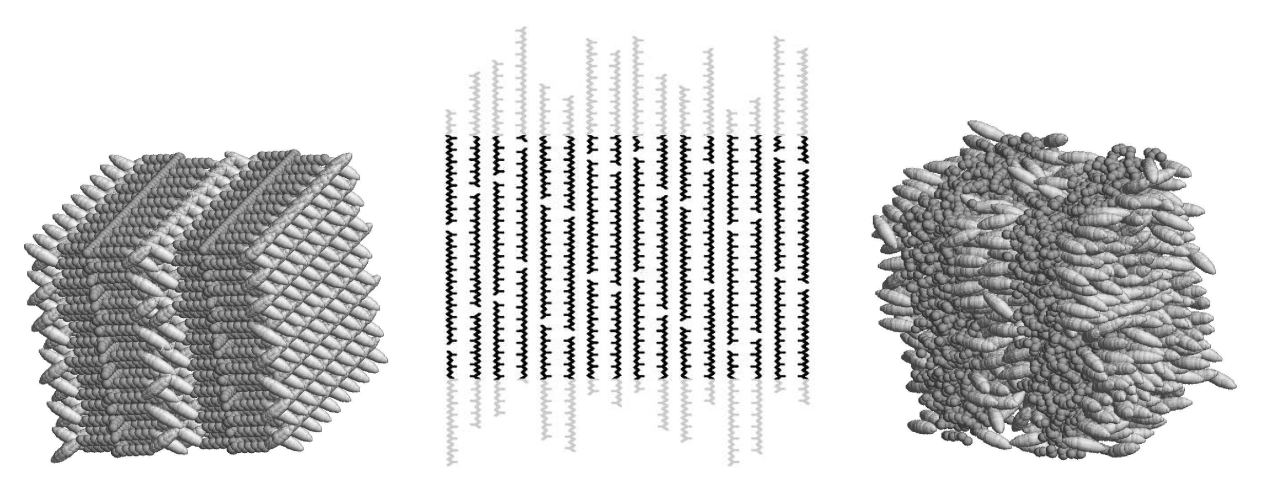

Figure 3. Initial geometrically packed configuration (on the left), backbones interdigitation along the $X$ axis (in the middle) and equlibrated configuration after simulation for $4 \mathrm{~ns}$ at atmospheric pressure $P=P_{\mathrm{atm}}=1 \mathrm{~atm}$ at $T=500 \mathrm{~K}$ (on the right).

This initial configuration was equilibrated then for the times of up to 4 ns at atmospheric pressure $P=P_{\text {atm }}=1$ atm and at different temperatures $T$ ranging from $200 \mathrm{~K}$ to $600 \mathrm{~K}$. The molecular dynamics was performed with the aid of the parallel program GBMOLDD $[21,23]$ in an anisotropic NPT ensemble with the timestep ranging from 1 fs to $1.5 \mathrm{fs}$. The Hoover barostat has been used to fix the tensile stress at $P_{\mathrm{xx}}=P_{\mathrm{yy}}=P_{\mathrm{zz}}=P_{\mathrm{atm}} / 3=1 / 3 \mathrm{~atm}$, and the temperature has been controlled by means of the Nose-Hoover thermostat. The ensemble chosen allows independent fluctuations for each box dimension and proved to be especially useful to simulate smectic and crystal phases to avoid the incommesurability of the box dimensions with the characteristic pitch of the phase.

The model system revealed crystalline, smectic and isotropic phases with the transition temperature from the smectic to the isotropic phase at $T_{\mathrm{SI}}$ just above $500 \mathrm{~K}$. At $T=500 \mathrm{~K}$ the system still has weak smectic order (see,figure 3 , on the right), but the proximity to $T_{\mathrm{SI}}$ allows us to easily perturb the delicate balance of internal interactions. This particular configuration equilibrated at $T=500 \mathrm{~K}$ and $P_{\text {atm }}$ (the corresponding mass density is $\rho=M / V=0.63 \mathrm{~g} / \mathrm{cm}^{3}$ ) was chosen to study the response of the system on an external model field defined via equation 1 with various strengths $F$. The field direction has been chosen to coinside with the nematic director of the original smectic configuration (see figure 3 , on the right) to maximize the reorientation effect.

The simulational setup described above has much in common with the experiments of Finkelmann's group on the photoresponse of nematic elastomers [12] except the fact that our system is built of non-crosslinked chains. However, on a short time scale the effect of chains diffusion can be neglected and the model system can be affinely deformed. In this case splitting of the macroscopic sample into a grid of adjacent cells will map the shape of each cell onto that of the whole sample. One can consider the simulation box (which is able to fluctuate freely in shape) as one of such cells. On a larger time scale, however, this does not hold due to chain diffusion.

To study the coupling of the sample shape with the LC order of the chromophores, we have monitored the scaled box dimensions, $s_{\mathrm{x}}=L_{\mathrm{x}} / V^{1 / 3}, s_{\mathrm{y}}=L_{\mathrm{y}} / V^{1 / 3}, s_{\mathrm{z}}=L_{\mathrm{z}} / V^{1 / 3}$ and the nematic order parameter $S_{2}=\left\langle P_{2}\left(\theta_{\mathrm{i}}\right)\right\rangle$ and analysed the snapshots of the systems in a course of the simulations. Here, $L_{\mathrm{x}}, L_{\mathrm{y}}, L_{\mathrm{z}}$ are the box dimensions, $V=L_{\mathrm{x}} L_{\mathrm{y}} L_{\mathrm{z}}$ is the volume of the box, $\theta_{\mathrm{i}}$ is 

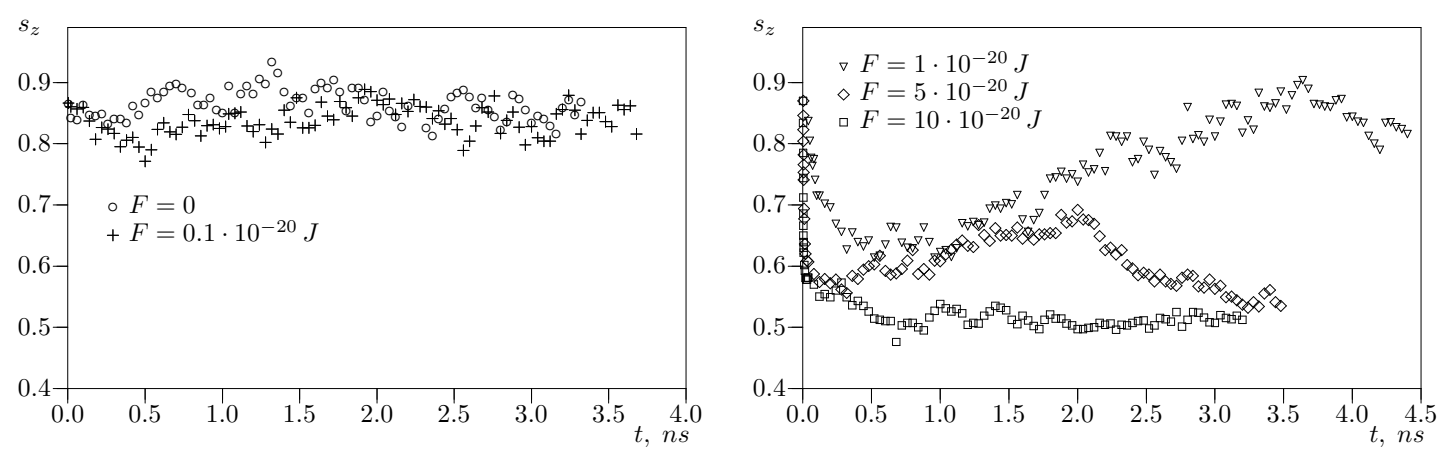

Figure 4. Box shape parameter $s_{\mathrm{z}}$ along the direction of the external model field $v s$ time, weak fields (left graph) and strong fields (right graph).

the angle between the long axis of the $i$-th chromophore with the nematic director and $P_{2}(x)$ is the second Legendre polynomial. One should mention that in the presence of an external field one can measure the nematic order either in respect to the field direction or in respect to the instantaneous director of the chromophores. For our simulational setup, the former will only confirm that the chromophores are indeed perpendicular to the field (the order parameter defined in this way will be equal to $-1 / 2$ ), whereas the latter will also provide the level for chromophores self-organizations (if any) in other directions. The usual procedure for the calculation of the order parameter is as follows. At each time $t$ the instantaneous order parameter tensor is evaluated first, then it is diagonalised so that the maximum eigenvalue provides the value for the scalar order parameter $S_{2}$. All the simulations were performed at fixed temperature $T=500 \mathrm{~K}$ and atmospheric pressure $P_{\mathrm{atm}}$ while the box shape was allowed to fluctuate. The $Z$ axis was chosen along the nematic director of the original smectic phase. The model field has been applied in the same direction.

For a weak field strength, $F=0.1 \cdot 10^{-20} \mathrm{~J}$, no changes of the box shape were observed at all times studied (up to $4 \mathrm{~ns}$, see figure 4 , on the left). On the contrary, the case of stronger field strengths, $F \geqslant 1 \cdot 10^{-20} \mathrm{~J}$, reveals an analogy with the experiments on nematic elastomers. Here a quick initial contraction of the box was observed along the field direction (see, figure 4, on the right).
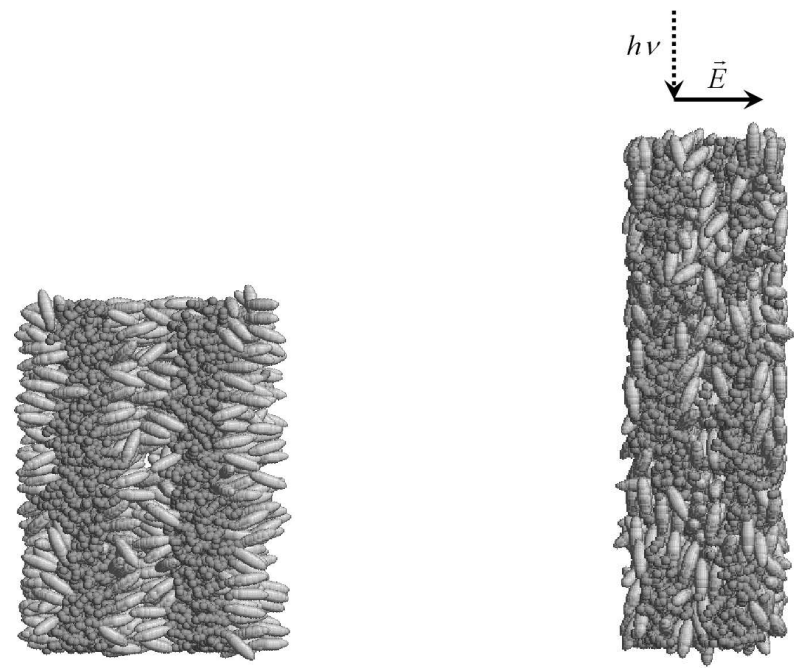

Figure 5. Snapshots of the model system at times $t=0$ (left image) and $t=10 \mathrm{ps}$ (right image) at a temperature $T=500 \mathrm{~K}$, the light propagation is shown by a dotted arrow whereas the field direction is designated as $\vec{E}$, the field strength parameter is $F=5 \cdot 10^{-20} \mathrm{~J}$. 
This contraction was accompanied by the extension of the box in the other two dimensions, so that no apparent change in the average material density has been observed. The side-by-side comparison of the snapshots of the system at time $t=0$ and that at $t=10 \mathrm{ps}$ in a strong field $F=5 \cdot 10^{-20} \mathrm{~J}$ (see, figure 5) suggests that the contraction of the sample has its origin in steric interactions. At time $t=0$, in the smectic phase, the long axes of the azobenzenes are aligned preferentially along the $Z$ axis. After applying the external field in the same direction, this order melts within $c a . t=10 \mathrm{ps}$ as being energetically unfavourable and a new orientational order with the azobenzenes perpendicular to the $Z$ axis is started to be induced. This quick reorientation happens on a time scale far less than that of the chains diffusion, so that, the voids emerging around the azobenzenes cannot be filled. As a result, the material contracts rapidly along the $Z$ axis. One can conclude that the material demonstrates an elastic response to a strong external field, similar to the elastomer system, on a short time scale.
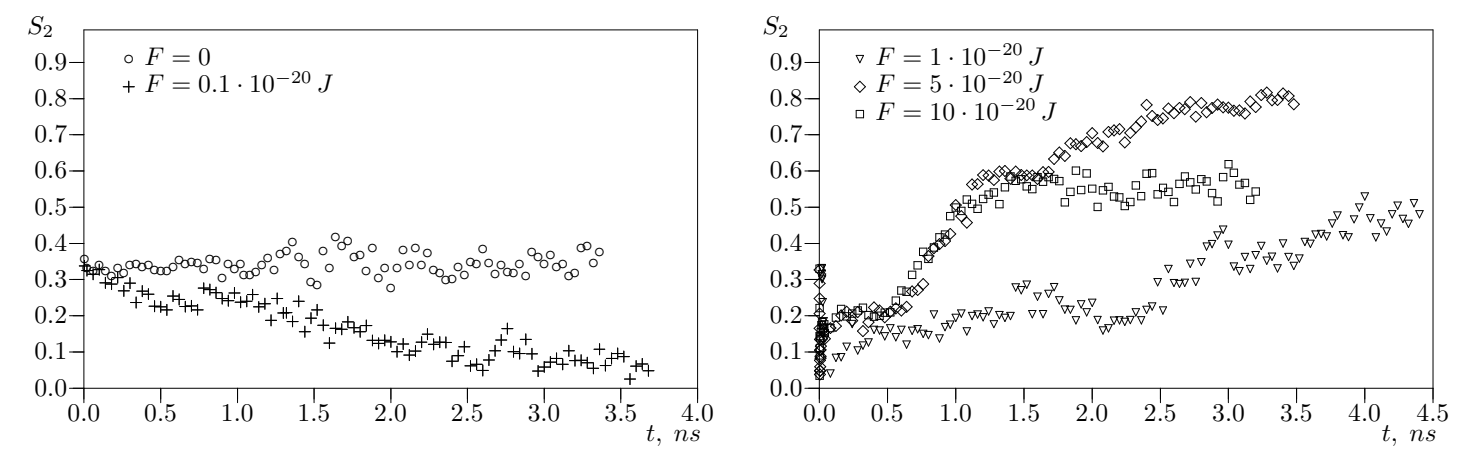

Figure 6. The orientational order parameter $S_{2}$ for the chromophores $v s$ time, weak fields (left graph) and strong fields (right graph).
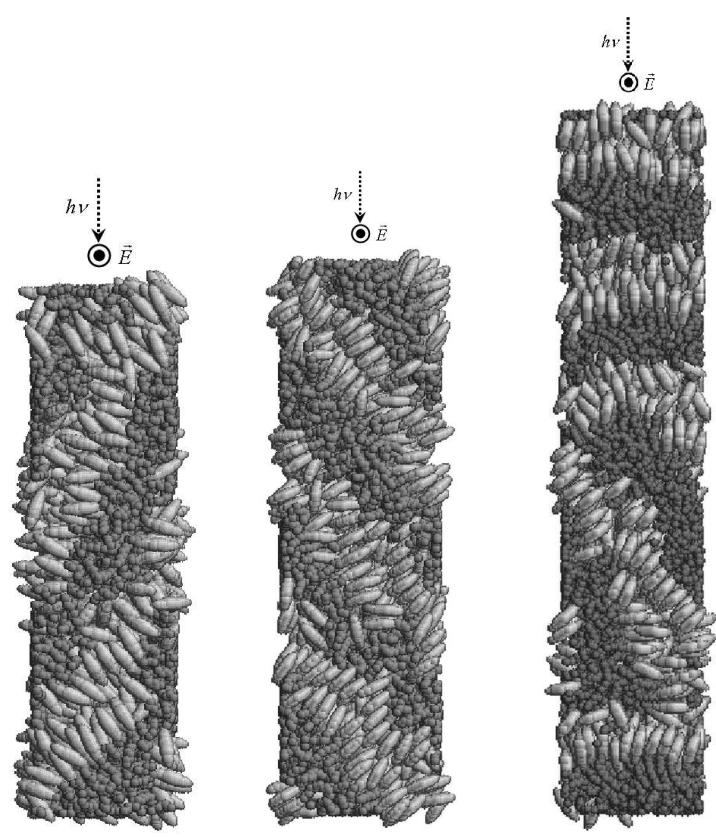

Figure 7. Self-organised smectic layers in planes perpendicular to the field direction $\vec{E}$ (directed towards the observer) after the time $t=4 \mathrm{~ns}$ and field strength $F=1 \cdot 10^{-20} \mathrm{~J}$ (left image), $F=5 \cdot 10^{-20} \mathrm{~J}$ (middle image) and $F=10 \cdot 10^{-20} \mathrm{~J}$ (right image), the light propagation is shown by a dotted arrow. 
The shape of the simulation box on a longer time scale is of lesser interest as far as chain diffusion smears out its resemblance to the shape of the macroscopic sample. However, the dynamics of the orientational order parameter $S_{2}$ is of interest. One should mention that the behaviour of the order parameter in a weak field reveals only slow "melting" of the initial smectic phase (see, figure 6 , on the left). The time scale of this process is comparable with the chains diffusion kinetics and neither changes of the box shape nor regrowing of new phases have been observed up to times of $4 \mathrm{~ns}$ (see, figure 4, 6 on the left).

In the case of a stronger field, after an initial quick fall-down, the order parameter $S_{2}$ grows until it reaches a final new value, for instance $S_{2} \sim 0.8$ for $F=5 \cdot 10^{-20} \mathrm{~J}$ (see, figure 6 ). During this process, all the chromophores reorient preferably perpendicularly to the field direction, and self-organize into new smectic layers (see, figure 7).

One should mention that in a very strong field, $F>10 \cdot 10^{-20} \mathrm{~J}$, the structure of the ordered phase is a polysmectic with many possible defects, as a result of quick formation of smectic clusters with rather high interfacial energy.

To summarize the results, our simulations of a side-chain azo-polymer subjected to a external model field, reproduce some of the features of real photo-active polymers observed previously in experiment. In weak fields, only a photo-chemical smectic-isotropic transition is observed [24] with no apperent change of the polymer shape. In stronger fields, on a short time scale, photo-induced contraction of the sample in the direction of light polarization is observed (the effect similar to the one in nematic elastomers [12]), whereas on a longer time scale the reorganisation of smectic layers is observed (for more details, see. [25]).

\section{Conclusions}

This study considers molecular dynamics simulations of a model side-chain azo-polymer subject to an external model field which approximates some aspects of the photoisomerization of trans azobenzenes. In weak fields a photo-chemical smectic-isotropic transition is reproduced, while in stronger fields, the short time scale behaviour is similar to the photoresponse of azobenzenecontaining elastomers. On longer time scale, reorganisation of smectic layers in strong fields is observed.

The results obtained in this study confirm that the chromophore reorientation may play a significant role in photo-induced effects in azo-polymers. In particular, both effects of reversible contraction/extension of LC elastomers and SRG formation in LC side-chain polymers might be of the same microscopic origin, as was already suggested before [16]. More detailed modelling is needed to describe other aspects of photoisomerization which will be subject of subsequent studies.

\section{Acknowledgements}

The authors acknowledge the financial support under DFG Grant NE410/8-1 and computer time offered by Computing Cluster of the Institute for Condensed Matter Physics, Lviv, Ukraine.

\section{References}

1. Ho C.H., Yang K.N., Lee S.N., J. Polym. Sci. A, 2001, 39, 2296.

2. Saphiannikova M. et al., J. Chem. Phys., 2003, 118, 9007-9014.

3. Goodby J.W. et al., J. Mater. Chem., 2001, 11, 2631.

4. Wu Y. et al., Macromol., 1998, 31, 1104; ibid., 1998, 31, 4457.

5. Ubukata T., Seki T., Ichimura K., Adv. Mater., 2000, 12, 1675.

6. de Gennes P.G., Phys. Let. A, 1969, 28, 725; Acad. Sci. Ser. B, 1975, 281, 101.

7. Finkelmann H., Wermter H., Abstr. Pap. Am. Chem. Soc., 2000, 219, 189.

8. Warner M., Gelling K.P., Vilgis T.A., J. Chem. Phys., 1988, 88, 4008.

9. Warnew M., Terentjev E.M. Liquid Crystal Elastomers. Clarendon, Oxford, 2003.

10. Cviklinski J., Tajbakhsh A.R., Terentjev E.M., Eur. Phys. J. E, 2002, 9, 427.

11. Yu Y., Nakano M., Ikeda T., Nature, 2003, 425, 145. 
12. Camacho-Lopez M. et al., Nature Materials, 2004, 3, 310.

13. Rochon P., Batalla E., Natansohn A., Appl. Phys. Lett., 1995, 66, 136; Kim D., Tripathy S., Lian L., Kumar J., Appl. Phys. Lett., 1995, 66, 1166.

14. Viswanathan N.K. et al., J. Mater. Chem., 1999, 9, 1941.

15. Yager K.G., Barrett C.G., Curr. Op. Sol. St. Mat. Sci., 2001, 5, 487.

16. Saphiannikova M., Neher D., J. Phys. Chem. B, 2005, 109, 19428.

17. Kasha M. Spectroscopy of the Excited State. Plenum, New York, p. 337, 1976.

18. Lagugne Labarthet F. et al., Macromol., 2000, 33, 6815.

19. Kim B.J., Park S.Y., Choi D.H., Bull. Korean Chem. Soc., 2001, 22, 271.

20. Gay J.G., Berne B.J., J. Chem. Phys., 1981, 74, 3316.

21. Ilnytskyi J.M., Wilson M.R., Comp. Phys. Comm., 2001, 134, 23.

22. Martin M.G., Siepmann J.I., J. Phys. Chem. B, 1999, 103, 4508.

23. Ilnytskyi J.M., Wilson M.R., Comp. Phys. Comm., 2002, 148, 43.

24. Ikeda T. et al., Macromol., 1990, 23, 36.

25. Natansohn A., Rochon P., Can. J. Chem./Rev. Can. Chim., 2001, 79, 1093.

\title{
Фото-індуковані деформації азобензинових полімерних гребінців: моделювання за допомогою молекулярної динаміки
}

\author{
Я.Ільницький ${ }^{1,3}$, М.Саф'яннікова², Д.Неєр ${ }^{1}$ \\ 1 Інститут Фізики, Потсдамський університет, \\ ам Ноєс Пале 10, 14469 Потсдам, Німеччина \\ 2 Інститут полімерних досліджень ім. Ляйбніца, \\ вул. Гое 6, 01069 Дрезден, Німеччина \\ 3 Інститут фізики конденсованих систем НАН України, \\ вул. Свєнціцького 1, 79011 Львів, Україна
}

Отримано 28 серпня 2005 р., в остаточному вигляді - 23 січня 2006 р.

\begin{abstract}
За допомогою методу молекулярної динаміки вивчається поведінка рідкокристалічних азобензинових полімерних гребінців в модельному зовнішньому полі, яке моделює переорієнтування азобензинових груп (хромофор) при опроміненні поляризованим світлом. Зокрема, у смектичній Фазі полімеру, при умові співпадіння напрямку зовнішнього поля із напрямком нематичного директора хромофор, відбувається переорієнтація хромофор перпендикулярно до напрямку прикладеного поля (який може бути асоційований із поляризацією світлового пучка). Знайдено, що взаємозв'язок між переорієнтацією хромофор та механічними деформаціями зразка суттєво залежить від величини прикладеного поля. В слабкому полі смектичний порядок повільно розмивається без зміни форми виділеного фрагменту зразка, в сильному ж полі спостережено два режими. Під час першого із них швидке руйнування смектичної фази супроводжується скороченням фрагменту полімера вздовж напрямку поля (ефект, аналогічний до експериментально спостережуваного ефекту скорочення нематичного фото-еластомера при опроміненні). Під час же другого, повільнішого, режиму смектичний порядок поступово перебудовується в такий спосіб, що хромофори тепер розташовані перепендикулярно до прикладеного поля.
\end{abstract}

Ключові слова: рідкі кристали, азобензин, полімери, молекулярна динаміка

PACS: $31.15 . \mathrm{Qg}, 64.70 . \mathrm{Md}, 64.70 . \mathrm{Nd}$ 